\section{CROSS-BORDER COOPERATION AS A TOOL OF ESCAPING CRISIS CONDITIONS IN SLOVENIA}

\section{Simona KUKOVIČ Miro HAČEK}

\author{
Simona KUKOVIČ \\ Assistant Professor, Department of Political \\ Science, Faculty of Social Sciences, \\ University of Ljubljana, Ljubljana, Slovenia \\ E-mail: simona.kukovic@fdv.uni-lj.si \\ Miro HAČEK (Corresponding author) \\ Professor, Department of Political \\ Science, Faculty of Social Sciences, \\ University of Ljubljana, Ljubljana, Slovenia \\ Tel.: 0038-615.805-179 \\ E-mail: miro.hacek@fdv.uni-lj.si
}

\section{Abstract}

The article puts an emphasis on cross-border cooperation between Slovenian municipalities and municipalities in neighboring countries of Croatia, Austria, Hungary and Italy. The aim is to analyze different paths and methods of cross-border cooperation Slovenian municipalities are using in order to further own development and somewhat escape financial crisis conditions autonomously. In Slovenia every third municipality is border municipality, which means that at least small part of their territory borders with the territory of municipality in one of the neighboring four countries. Since the central government does not rigidly regulate cross-border cooperation, but allows municipalities autonomy, each municipality can in its own way develop various forms and degrees of cooperation which are more or less intensively reflected in the proper functioning of these municipalities. In this sense we present our thesis that cross-border cooperation is becoming one of the important sources of investment and economic development of otherwise heavily crisis-affected local communities in Slovenia.

Keywords: cross-border cooperation, municipalities, crisis, resources, Slovenia. 


\section{Introduction}

No country in the world has developed its own territory uniformly. The most under-developed areas are usually along the border away from the main centers of power, decision-making and main financial resources. Frontier areas (both municipalities and regions) usually lack both social and economic development. The border areas are largely excluded not only physically but also economically, culturally and socially. This exclusion is an incentive to connect with similarly deprived areas that are located across the national border. Such areas play a transitional role in cooperating with cross-border areas to promote the exchange of information, experience, culture and economy in the attempt to preserve the diversity. Cross-border or trans-frontier cooperation is thus defined as the cooperation between the territories of neighboring countries and the territories in additional bordering countries (i.e. trans-boundary cooperation) with the aim of establishing links and contractual relations, which are aimed at seeking common solutions to similar problems that are connected mainly with the lack of economic development. Cross-border cooperation can be grouped into categories, such as employment, economic development, tourism, culture, education, infrastructure, environment and spatial planning. The relationships of bordering municipalities (i.e. intensity) may develop on at least four hierarchical levels, including information, consultation, cooperation and integration.

In Europe, the cross-border cooperation between local communities has a long tradition. In the adoption of the Madrid Convention (1980), the Council of Europe outlined the development of specific forms of cross-border cooperation. Another important actor is the European Union, which promotes the cross-border cooperation of local authorities and provides strong financial incentives. In Slovenia, 75 of the 212 municipalities (35\%) are border municipalities, which means that their territory is bordered by a municipality in a neighboring country. Because the central government does not rigidly regulate cross-border cooperation but allows the extensive autonomy of municipalities, each municipality can develop various forms and degrees of cooperation, which are more or less intensively reflected in their functioning. Hence, we present the following thesis: cross-border cooperation has become one of the most important sources of investment and development of otherwise heavily crisis-affected local communities in Slovenia. This article focuses on the cross-border cooperation between municipalities in Slovenia and in the neighboring countries of Croatia, Austria, Hungary and Italy. In particular, the article analyses the different paths and methods of cross-border cooperation that Slovenian municipalities use autonomously to further their development and escape crisis conditions.

This paper is organized as follows. In the next section, we examine the roots of cross-border cooperation in local European governments. The third section of the paper provides the contextual settings of our case study, and the fourth section describes and analyses the data collected from the empirical survey, which was completed by all Slovenian border municipalities. The final section draws conclusions based on the results of the analysis. 


\section{The concept of cross-border cooperation}

Traditionally, the borders between countries have been seen as barriers and as a means of controlling territories. Borders enable differences, and they are obstacles to the transport of people and goods between countries. This view was formed in the historical past when tribes, empires and countries struggled to gain control of territories. Even today, such disputes over borders persist across the globe. However, in Europe the importance of borders as barriers has decreased between the member states in the European Union (EU), especially in the Schengen area. This development began in the late 1980s, when trade and other contacts between the member states increased significantly because of the Single Market program. Moreover, it has been recognized that borders create opportunities. The differing conditions across a national border can be utilized to benefit development. The utilization of a border as a gateway means that it is a resource for those moving across it, and it generates benefits that would not exist if the border were not in place.

In Europe, cross-border cooperation began to develop in the 1950s, particularly in the Rhine Basin, which involved border areas in France, Germany, Switzerland, Luxembourg, Belgium and the Netherlands. The importance of local communities in cross-border cooperation has been emphasized to increase competitiveness (Mattsson and Pettersson, 2005). Today, the cooperation across borders that delineate large structural disparities can be divided into three separate stages of development (Järviö, 2011 , p. 4). In the first stage, the lesser-developed party has little capability for real cooperation with the local communities in the member state across the border. The local communities in the member state provide expertise and training, organize study visits to the member state across the border, and conduct feasibility and other studies on the development potential of the border area. These activities create important networks between the member states on both sides of the border. In the second stage, plans are drawn up with a view to social and economic convergence between the local communities on both sides of the border. Convergence is promoted through planning investment projects that rarely attract outside financing and have little relation to the actual nature of cross-border cooperation. In the third stage, the local communities on both sides of the border recognize the potential for development that it provides. The differences between local communities are exploited to benefit both communities. Eventually, investments are focused on the infrastructure to facilitate border crossing. Regional and municipal bodies develop joint projects. In addition, direct contacts between the citizens and communities along the border are supported.

Cross-border cooperation is currently concerned with keeping territories together based on various types of interactions and transactions, such as the flows of information, goods and people (Mattsson and Pettersson, 2005). In general, we can say that cross-border cooperation has four objectives: to address common challenges, to promote economic and social development in border areas, to ensure efficient and secure borders, and to promote cooperation between people. A dominant argument for cross-border cooperation is that the empowered local communities along the bor- 
der leads to the production of efficient and effective services, which improves the lives of individual citizens as well as other partners and stakeholders. Cross-border cooperation includes different integration processes from small and temporary activities to powerful and sustainable projects, such as regional building projects, which are financially supported by transnational authorities. According to Passi (1986), the process of cross-border regional building consists of different development stages that gradually lead to internal cohesion and external separation. Local communities along the border have to develop powerful processes of integration, and they must be involved in different networks in order to enable knowledge production, labor competence and service provisions to satisfy the citizens (Copus, 2001). The goal is to develop and create strong, long-lasting and sustainable cooperation networks. According to Wiberg (apud Mattsson and Pettersson, 2005, p. 99), the basic purpose of this cooperation is to be useful to each other by similar or complementary effects, such as gaining access to a variety of services and cultural activities. Another goal is to reduce the disparities and hierarchical power relation between the center and periphery as well as between urban and rural areas (European Union, 2004). Moreover, cross-border cooperation fosters contacts between individuals as well as networks between local communities (Stubb apud Järviö, 2011, p. 1). It contributes to the establishment of a common border-region identity, and it facilitates the generation of social capital, trust and mutual understanding among the communities on both sides of the border. Finally, cross-border cooperation leads to better relations between the neighboring countries, and the EU funding for such cooperation contributes to the stability and prosperity of the border areas in the EU. Such funding is essential for some border local communities, especially in recovering from economic and financial crises, when seeking external financial resources is a key task that often is the only opportunity for development.

\section{Context: Relations between the Slovenian municipality and the Slovenian state}

\subsection{The legal framework of municipal competences}

As a rule, all modern states include the basic principles of local government functioning in their constitutional documents. The general provisions (Article 9) of the Constitution of the Republic of Slovenia guarantee local government to all citizens. Hence, the local government has become a constitutional category. The constitutional provisions for local government are general because detailed regulations are provided by the law. Local governments mainly implement the policies made at a higher level instead of creating their own policies (Kukovič, 2015). The result is an unequal division of competences between the state and the local governments. The regulations of local governments do not provide much room to formulate independent policy in certain areas; therefore, we can only talk about relative autonomy (Schultz, 1979, p. 79; Brezovšek and Kukovič, 2012, p. 60). Local government is primarily based on the clear division of responsibilities between the state, its bodies and local community bodies. The main objective of the regulation of the relationship between the state and 
the local communities is to allow the municipality to obtain under authentic competence the functions that are essential for the life and work of its inhabitants, which are more effectively and rationally exercised within the local community than through the state authorities (Vlaj, 1997, p. 45).

In Slovenia, the municipal competencies are relatively narrowly defined in the Constitution. The first paragraph of Article 140 provides that the jurisdiction of the municipality comprises local affairs that are governed autonomously by the municipality and that affect only the inhabitants of the municipality. Slovenian municipalities are therefore not responsible for exercising all the public functions in their territory (unlike German municipalities for example) but only in matters of local importance. The Constitution does not analyze in detail local issues that are not in the municipality's authentic jurisdiction. Thus, the legislation ${ }^{1}$ deals with the issue of municipal competences, and applies the terms 'own and delegated competencies'. Municipalities' own competencies reflect the fact that they comprise local affairs that may be regulated autonomously and that affect only the residents of the municipality. Upon prior agreement with the municipality, the state may transfer specific duties to the municipality, if it also provides the financial resources required. This transfer of certain state competences to the municipal level may, on the one hand, be understood as a regulation that prevents the state from intervening in the autonomy of the local community; on the other hand, it may represent an insurmountable obstacle to the transfer of state functions to municipalities. The latter is also characteristic of Slovenia because the municipalities have not been delegated competencies for more than two decades.

In matters of municipality competences, the Local Government Act limits the state rather than the municipality. It prevents the state from interfering in the municipalities' governing sphere. The Local Self-Government Act (2007) classifies the tasks that are independently governed by the municipality into six groups:

1. In the field of normative regulation, the municipality adopts municipality ordinances and other municipal acts, the municipal budget, the municipality development plan and annual accounts, and so on.

2. In the field of governance, the municipality manages the municipal property and local public services, public and other companies, the municipal public areas and other public goods, local public roads and other routes.

3. With its own resources, the municipality builds and maintains local public roads and other routes, promotes cultural and social activities and so on.

4. With its own measures, it encourages the economic development of the municipality, provides fire safety, orderly waste collection and so on.

5. It provides assistance in the supervision of local events and rescue measures in the event of natural disasters.

1 The Local Government Act, Official Gazette of RS, no. 94/07 - official consolidated text, 76/08, 79/09, 51/10, 40/12 and 14/15. 
6. It concludes contracts on the acquisition and alienation of movable and immovable property, concessions, the use of the public good and other relationships into which the municipality enters.

It should be noted that the work performed by the municipality is governed primarily by sectorial legislation. Thus, the municipality competences are also governed by laws such as the Roads Act, Environmental Protection Act, Kindergarten Act, and so on. Nevertheless, there are numerous conflicts in connection with the competences of the municipality and the state in which the Constitutional Court of Republic of Slovenia interferes.

\subsection{The problem of municipal financing}

Many experts who deal with the relationship between the state and local communities noted that the area of funding is crucial to the status of local communities and their autonomy. The financial autonomy of municipalities significantly contributes to the image of a democratic state and the autonomous local authority. Page (1991, p. 31) argued that one of the methods used to assess the decisions made by local authorities is the degree to which they can independently increase the tax burden on the population. The legal authorization to perform certain tasks is meaningless if the local authorities lack financial resources. The basic obligation of elected local representatives is to make political decisions about the benefits of the provided services and the taxpayers' costs (Vlaj, 1998, p. 313). The lack of financial resources changes local communities in the executive bodies of state administration. Therefore, we have observed the recent tendency to introduce local public finance systems that are optimally independent of the state authorities. The municipalities' taxes and contributions enhance their autonomy, but only if they can be regulated according to their own tax base at their own tax rate. The autonomy of the local government is recognized in the possibility that the municipality can prescribe specific municipal taxes in order to finance its basic functions. In this respect, local governments are not directly tied to conditions that are otherwise prescribed by tax legislation. However, in prescribing other taxes such as charges, utility charges, and so on, the municipality is bound by the legal conditions (Vlaj, 1998, p. 86; see also Brezovnik and Oplotnik, 2012, p. 280).

Slovenia does not have a so-called regional level of decentralization. The only decentralized level consists of the 112 municipalities, of which 11 are so-called 'urban municipalities' or municipalities with urban status (i.e. large cities). During the last decade, approximately $12 \%$ of total public finance (5.5\% of the GDP) was earmarked for local finance (Oplotnik et al., 2012, p. 129). Article 142 of the Slovenian Constitution specifies that the municipalities are financed by their own resources. However, if the municipality fails to ensure the performance of the tasks because of its poor economic development, the state must allocate additional resources to the municipality. Theoretically, the financial needs of local self-government are supposed to be met primarily according to the principle of resource proportionality of tasks and autonomy (Buchanan and Musgrave, 1999). The Local Government Act of 1993 has not been 
amended to state that: a) the municipality's sources of financing include own resources, state resources and borrowings or b) the municipality's finance are local matters of public importance. According to the Court of Audit of the Republic of Slovenia (2012, p. 29), the structure of the municipal finances in the period from 1994 up to and including 2010 consisted of $79.4 \%$ of own resources, $17.2 \%$ of government funding and $3.4 \%$ of borrowed funds ${ }^{2}$. Since 2006, the new Financing of Municipalities Act (ZFO1 ), which is not fully harmonized with the Local Self-Government Act, has governed the financing of the tasks that are within municipal competences ${ }^{3}$. In connection with own tax resources, the ZFO-1 indicates the revenues of the municipal budget, namely personal income tax, property tax, tax for the use of local building lands, tax on inheritance and gifts, tax on winnings from classic gaming and other taxes, as defined by the law that regulates individual tax. It should be noted that the share of personal income tax allocated to the municipalities increased from 35\% in 1998 to 54\% in 2014 in series of governmental attempts to increase the sustainable development of both urban and rural municipalities.

The tax for the use of local building lands is the only substantial revenue source over which municipalities have independent control. All other tax revenues are controlled and set by the state, which in effect diminishes the autonomy of the municipalities and increases the power of the state over them. Because the economic crisis also affected municipal revenues in the last decade, in 2012 the state decided to ignore its own legislation and allocate lower state co-financing to local governments ${ }^{4}$. Both the Association of Municipalities and Towns of Slovenia and the Association of Municipalities of Slovenia opposed government proposals to the lower state co-financing of local governments. The municipalities rightfully claimed that they are autonomous according to the Constitution and the European Charter on Local Self Government,

2 With the adoption of the new Financing of Municipalities Act (ZFO-1 2006), the structure of the sources of municipal finances changed. In the period between 1994 and 2006, it consisted of the following: $78.3 \%$ in municipal resources, $20 \%$ in state funds and $1.7 \%$ in borrowed funds. During the period between 2007 and 2010, it consisted of $80.9 \%$ in municipal resources, $13.1 \%$ in state funds and $6.0 \%$ in borrowed funds.

3 The financing of municipalities is based on the principles of the European Charter of Local Self-Government, in particular the principles of financial resource proportionality to the tasks of the municipalities and the principle of the municipalities' autonomy in financing municipal tasks (ZFO-1 2006, article 3). The principle of proportionality is also taken into account in financing tasks under state jurisdiction that the state transfers to the municipality by law. In accordance with the ZFO-1, the state must determine the method of state financing by law, upon which it transfers to the municipality the performance of specific tasks within its jurisdiction; the funds must be commensurate with the nature and extent of the delegated tasks (ZFO-1 2006, article 5).

4 In 2016, municipalities received only $80 \%$ of the finances that they should get according to the legislation. In this way, the state saved 1,208 billion Euros in the period from 2011 to 2016, which represents approximately two \% of national budgets in the stated period (Association of Municipalities and Towns of Slovenia, 2016). 
which was adopted in Slovenia in 1996. The government is therefore required to provide adequate financing (Haček, 2016). In September 2015, both associations of municipalities went before the Constitutional Court to file a lawsuit against the state, asking it to fulfil its contractual financing obligations for 2015.

The amount of state financing to municipalities will remain well under what requires the legislative framework in 2017 and 2018, according to the national budgets for that period, which forces the municipalities in two directions: first, there are on-going legal processes between the state and the municipalities over the (lack of) state co-financing; second, the municipalities will continue the search for financial rationalization ${ }^{5}$ and additional external resources, mainly through using the mechanisms available to acquire funds from the EU and, although they are somewhat limited to border municipalities, cross-border cooperation projects.

\section{Empirical analysis of cross-border cooperation}

There are no obstacles to the cross-border cooperation between Slovenian municipalities and Italian, Austrian, Hungarian and Croatian municipalities. Neither the Constitution nor the legislation governing local self-government imposes any limitations on such forms of cooperation. However, in practice, real problems occur in establishing cooperative relations. Certain legislation, such as regarding financial flows, not directly concerning cross-border cooperation may represent a serious obstacle to its implementation. Other problems are derived from the fact that Slovenia has a one-tier local government system, in which the municipalities are forced to act not only as a local entity but also as a regional entity in developing several multilateral agreements, such as those that have established the 'working group' Alpe Adria or other regional associations in the Alps-Adriatic-Pannonian macro region. The aim of such agreements is to exchange opinions, organize joint consultations, prepare declarations of intent regarding the introduction of cooperation programs, and draw up legally binding agreements (Bufon and Markelj, 2010, p. 23). With the help of indepth questionnaires we ascertained that especially middle and smaller sized municipalities (with under 10,000 inhabitants) have difficulties acting not only as local, but also as regional entities, as often such municipalities do not have sufficient human and organizational resources available; in this sense mayors have expressed expectation that the state could provide some assistance in similar cases, not necessarily in terms of providing municipalities with additional financial resources, as this is seen as rather unrealistic, but in terms of extending and upgrading the policy of co-financ-

5 Since the beginning of 2006, the municipalities that organize the common performance of individual municipal administrative tasks was granted in accordance with the Financing of $\mathrm{Mu}-$ nicipalities Act (ZFO-1, Article 26) additional funds for the current year from the state budget for percentage of the realized municipal budget expenditure in the previous year for financing common tasks. This greatly increased the number of common municipal administrations and the number of employees, especially in the period of the financial crisis after 2008. 
ing common municipal administrative bodies also to the area of cross-municipal cooperation $^{6}$.

The examination of the financial structure of municipal revenues in $2015^{7}$ revealed that all 212 Slovenian municipalities acquired $15 \%$ of their total annual budgets from various EU funds ${ }^{8}$, mainly (75.8\%) from cohesion funds. There are currently four special Interreg programs in place for Slovenia (one for each of the cross-border cooperation projects with four neighboring countries) with a total value of 223 million EUR in the financial prospects of the period 2014 to 2020.

We used a short questionnaire ${ }^{9}$ to acquire information about the current levels of cross-border cooperation between Slovenian and the border municipalities in neighboring states. We expected to find relatively extensive municipal cross-border cooperation as a mechanism used to increase financial autonomy. As Table 1 shows, all 45 municipalities involved in the cross-border cooperation were cooperating in the fields of tourism, culture and education. The municipalities reported less cooperation in the infrastructure (47\%) and cross-border initiatives, and even less in the field of environment and spatial usage (40\%). The least developed field of cooperation was the labor market and economy $(22 \%)$, but according to the feedback received from the municipalities, this was largely because of the lack of competencies in Slovenian municipalities. The findings showed that more demanding and less represented fields of cooperation (i.e. environment, spatial usage, labor market and economy) were more common in larger municipalities, that is, those that have more than 10,000 inhabitants $^{10}$.

6 Slovenian central government is for the last decade co-financing (in the amount of 50\%) human resources, employed in specially established common municipal administrative (CMA) bodies that provide public services for the territory of two or more municipalities. Such CMAs have to be established by all participating municipalities. CMAs are often seen as one of the most successful national policies, aiding to the municipal autonomy and enabling equal distribution of public services in the national territory (Kukovič et al., 2016, 308-312).

7 Data from the Ministry of Finance (2016).

8 If we compare this figure with the data from the previous budgetary periods, we ascertain that the number is indeed rising. In 2014, municipalities acquired $15.7 \%$ from various European Union funds; in 2013, this figure was 7.5 \%, and in 2012, $7.3 \%$ (Ministry of Finance, 2016).

9 The empirical research was conducted in February and March 2016 by the researcher of the Centre for the Analysis of Administrative-Political Processes and Institutions (CAAPPI) at the University of Ljubljana, Slovenia. All Slovenian border municipalities (75) were invited to participate, and $52(69 \%)$ of them also filled out and returned the questionnaire. Of the 52 participating municipalities, twelve border Austria, six border Hungary, 22 border Croatia, five border Italy, and seven municipalities border two neighbouring countries. When asked about cross-border cooperation, 45 (87\%) confirmed that they cooperated with at least one neighbouring municipality, and seven denied this involvement.

10 It is probably worth mentioning that the average Slovenian municipality has 9,650 inhabitants (Haček, 2016). 
Table 1: Usage of cross-border cooperation mechanisms in Slovenian municipalities

\begin{tabular}{|c|c|c|c|c|c|}
\hline Municipality & $\begin{array}{l}\text { Tourism, culture } \\
\text { and education }\end{array}$ & $\begin{array}{l}\text { Labor market } \\
\text { and economy }\end{array}$ & Infrastructure & $\begin{array}{c}\text { Environment } \\
\text { and spatial usage }\end{array}$ & Other fields \\
\hline $\begin{array}{c}\text { Below } 5,000 \text { inhabitants } \\
(\mathrm{N}=17)\end{array}$ & 17 & 2 & 4 & 7 & 6 \\
\hline $\begin{array}{l}5,001-10,000 \text { inhabitants } \\
(\mathrm{N}=9)\end{array}$ & 9 & 1 & 3 & 3 & 6 \\
\hline $\begin{array}{c}10,001-20,000 \text { inhabitants } \\
(\mathrm{N}=14)\end{array}$ & 14 & 4 & 7 & 7 & 5 \\
\hline $\begin{array}{c}\text { Above } 20,001 \text { inhabitants } \\
\qquad(\mathrm{N}=5)\end{array}$ & 5 & 3 & 3 & 1 & 3 \\
\hline $\begin{array}{l}\text { TOTAL } \\
(\mathrm{N}=45)\end{array}$ & 45 & 10 & 21 & 18 & 20 \\
\hline
\end{tabular}

In the next step, we enquired about the intensity of the cross-border cooperation between municipalities. We adapted a three-stage model based on the e-participation model, which was initially designed by OECD (Coleman and Gøtze, 2002, p. 250). In the first stage of the model, entitled information, the municipalities build a one-way relationship, in which they actively and passively acquire information, which is the basis and prerequisite of consultation and joint actions. In the second stage, entitled consultation, the municipalities build a two-way relationship, in which one municipality obtains feedback from other border municipalities regarding their opinions on common actions. The initiator municipality defines the problem and seeks opinions from other consulting border municipalities. In the third stage, entitled joint actions, a partnership is formed in which the municipalities are actively involved in shaping common actions and decision making about them. The final decision is always taken by all municipalities involved. The third stage is the most demanding. All municipalities involved are recognized as equal players in initiatives, planning common actions and making decisions about them. As Table 2 shows, the Slovenian municipalities involved in cross-border cooperation are the most involved in the information (91\%) and consultation (80\%) stages, which indicates their strong motivation for cross-border cooperation. However, most municipalities $(73 \%)$ were not involved in joint actions; stated reason for that is in most cases lack of adequate expertise of human resources and/or co-financing on the part of municipality.

Table 2: Cross-border cooperation according to the intensity levels

\begin{tabular}{lc}
\hline & No. of municipalities \\
\hline Information & $41 / 45(91 \%)$ \\
Consultation & $36 / 45(80 \%)$ \\
Joint actions & $12 / 45(27 \%)$ \\
\hline
\end{tabular}

When they were asked to evaluate the mechanism used in cross-border cooperation, $91 \%$ of the border municipalities viewed it as positive. The problems most often experienced by the municipalities involved the different legislative frameworks of the bordering countries, which sometimes made it difficult to manage cooperation 
in different actions. We also enquired about the importance of cross-border cooperation, and $40 \%$ of the municipalities specifically emphasized the huge importance of cross-border cooperation in culture, friendship building and tourism. Every municipality emphasized the importance of cross-border cooperation in finances and investment opportunities, often even claiming that without cross-border cooperation municipalities would not be able to implement any investments at all. We then asked about their plans for the future, and $90 \%$ of the municipalities emphasized that they wanted to further enhance cross-border cooperation in the near future.

\section{Conclusion}

The thesis of this article was formulated to test the assumption that the insufficient state financing in recent budgetary years has led local Slovenian communities in crisis to view cross-border cooperation as an increasingly important source of investment and economic development. We presented and analyzed objective and subjective data that clearly supported this assumption. In Slovenia, the system of municipal financing favors the state, which places its 212 municipalities in a highly dependent position, and they are forced to negotiate their state subsidies annually. A crisis situation is not particularly helpful in this regard. Of course, it cannot be denied that the easiest path for municipalities would be to obtain sufficient financial annual transfers from the state. However, the reality is that municipalities are forced to seek their own financial resources to preserve their autonomy and to ensure the continuous development of their local community. Hence, the municipalities have extensively increased their cooperation in projects funded by the EU and by their own actions. In this regard, they have fostered cross-border cooperation. We found that the financial resources deriving from cross-border cooperation have steadily increased, in addition to the willingness of the border municipalities to further intensify their cross-border cooperation. They are motivated to enhance their cooperation in cultural events, friendship building and tourism. They are also strongly motivated by the potential of cross-border cooperation to promote the financial stability of border municipalities.

Substantial financial resources are available for the financial period from 2014 to 2020, specifically for Slovenian cross-border actions and projects. Because $90 \%$ of border municipalities are resolved to enhance their efforts in cross-border cooperation in the short term, we can be very confident that the financial autonomy of the Slovenian municipalities will become even stronger in the near future.

\section{References:}

1. Association of Municipalities and Towns of Slovenia, 'Some Additional Arguments regarding Municipal Financing', 2016, [Online] available at http://www.cerkno.si/ wp-content/uploads/2016/01/gradivo_8_seje_2015_tocka_13_3.pdf, accessed on December 20, 2016.

2. Brezovnik, B. and Oplotnik, Ž.J., 'An Analysis of an Applicable System of Financing the Municipalities in Slovenia', 2012, Lex Localis, vol. 10, no. 3, pp. 277-295. 
3. Brezovšek, M. and Kukovič, S., Organizacija lokalne oblasti v Sloveniji (Organization of Local Authority in Slovenia), Ljubljana: Faculty of Social Sciences, 2012.

4. Buchanan, J.M. and Musgrave, A.R., Public Finance and Public Choice: Two Contrasting Visions of the State, Cambridge, MA: MIT Press, 1999.

5. Bufon, M. and Markelj, V., 'Regional Policies and Cross-Border Cooperation: New Challenges and New Development Models in Central Europe', 2010, Revista Română de Geografie Politică, vol. 12, no. 1, pp. 18-28.

6. Coleman, S. and Gøtze, J., 'Bowling Together: Online Public Engagement in Policy Deliberation', 2002, Journal of Information Polity, vol. 7, no. 4, pp. 247-252.

7. Copus, K.A., 'From Core Periphery to Polycentric Development: Concepts of Spatial and Aspatial Peripherality', 2001, European Planning Studies, vol. 9, no. 4, pp. 539-552.

8. Court of Audit of Republic of Slovenia, Revizijsko poročilo - ureditev področja občin (Revision Report - Municipal Management), Ljubljana: Court of Audit of Republic of Slovenia, 2012.

9. European Union, 'ESDP', 2004, [Online] available at http://europa.eu.int/scadplus/leg/ sv/lvb/g24401.htm, accessed on December 20, 2016.

10. Haček, M., 2016, 'Slovenia Country Report, Nations in Transit 2016', New York: Freedom House, 2016, [Online] available at https://freedomhouse.org/report/nations-tran sit/2016/slovenia, accessed on December 20, 2016.

11. Järviö, P., Cross-border Cooperation - Benefiting from Borders, Helsinki: Ministry of Foreign Affairs of Finland, 2011.

12. Kukovič, S., Lokalno politično vodenje: slovenski župani v primerjalni perspektivi (Local Political Leadership in Comparative Perspective), Ljubljana: Faculty of Social Sciences, 2015.

13. Kukovič, S., Haček, M. and Bukovnik, A., 'The Issue of Local Autonomy in Slovenian Local Government System', 2016, Lex Localis, vol. 14, no. 3, pp. 303-320.

14. Mattsson, M. and Pettersson, Ö., 'Cross-Border Collaboration in the North. Viewpoints of Municipal Representatives and Firm Managers on the Bothnian Arc Project', 2005, Fennia International Journal of Geography, vol. 183, no. 2, pp. 97-107.

15. Ministry of Finance, 2016, 'Finance Structure of Municipal Budgets', 2016, [Online] available at http://www.mf.gov.si/si/delovna_podrocja/lokalne_skupnosti/statistika/ podatki_obcin_o_realiziranih_prihodkih_in_drugih_prejemkih_ter_odhodkih_in_ drugih_izdatkih_splosnega_dela_proracuna_ter_o_realiziranih_odhodkih_in_dru gih_izdatkih_posebnega_dela_proracuna/, accessed December 20, 2016.

16. Oplotnik, Ž.J., Brezovnik, B. and Vojinovič, B., 'Local Self-Government Financing and Costs of Municipality in Slovenia,' 2012, Transylvanian Review of Administrative Sciences, 37E, pp. 128-142.

17. Page, E.C., Localism and Centralism in Europe. The Political and Legal Bases of Local Self-Government, Oxford: Oxford University Press, 1991.

18. Passi, A., 'The Institutionalization of Regions: A Theoretical Framework for Understanding the Emergence of Regions and the Constitution of Regional Identity', 1986, Fennia International Journal of Geography, vol. 164, no. 1, pp. 105-146.

19. Schultz, A., Local Politics and Nation-States, Oxford: Clio Press 1td, 1979.

20. Vlaj, S., Lokalna samouprava - občine in pokrajine (Local Self-Government - Municipalities and Regions), Ljubljana: Faculty of Social Sciences, 1998. 
21. Zakon o financiranju občin (Financing of Municipalities Act) (ZFO; FMA), Official Gazette of Republic of Slovenia no. 80/94, 45/97, 56/98, 1/99, 59/99, 79/99, 90/05 and 32/06.

22. Zakon o financiranju občin-1 (Financing of Municipalities Act - 1) (ZFO-1; FMA-1), Official Gazette of Republic of Slovenia no. 123/06, 57/08, 36/11 and 14/15.

23. Zakon o lokalni samoupravi (Law on Local Self-Government) (ZLS; LLSG), Official Gazette of Republic of Slovenia no. 72/93, 57/94, 14/95, 26/97, 70/97, 10/98, 74/98, 70/00. 94/00, 100/00, 28/01, 87/01, 16/02, 51/02, 94/07 - UPB3, 76/08, 79/09, 51/10, 40/12 and $14 / 15$. 